\title{
Estimating the Impact of Environmental Conditions on Hatching Results Using Multivariable Analysis
}

\begin{tabular}{l} 
QAuthor(s) \\
\hline Nääs IA ${ }^{1}$ \\
Gigli ACS \\
Baracho $\mathrm{MS}^{1}$ \\
Almeida Paz ICL \\
Salgado DD 1 \\
1 Agricultural Engineering College, State \\
University of Campinas, SP. \\
2 Faculty of Veterinary and Animal Science, \\
UNESP, Botucatu.
\end{tabular}

Mail Address

Irenilza de Alencar Nääs

Agricultural Engineering College

Campinas, SP, Brazil.

E-mail: irenilza@agr.unicamp.br

\section{Keywords}

Broiler chick, chick quality, hatchability, hatchery, incubation conditions.

\section{Acknowledgments}

The authors thank FAPESP and CNPq for funding this research study.

\section{ABSTRACT}

Hatching results are directly related to environmental and biological surroundings. This research study aimed at evaluating the influence of incubation environmental conditions on hatchability and one-day-old chickling quality of five production flocks using multivariable analysis tool. The experiment was carried out in a commercial hatchery located in the state of São Paulo, Brazil. Environmental variables such as dry bulb temperature, relative humidity, carbon dioxide concentration, and number of colony forming units of fungi were recorded inside a broiler multi-stage setter, a hatcher after eggs transference, and a chickprocessing room. The homogeneity of parameter distribution among quadrants inside the setter, the hatcher, and the chick room was tested using the non-parametric test of Kruskal-Wallis, and the fit analysis was applied. The multivariate analysis was applied using the Main Component Technique in order to identify possible correlations between environmental and production parameters. Three different groups were identified: the first group is represented by temperature, which was positively correlated both with good hatchability and good chick quality; the second group indicates that poor chick quality was positively correlated with air velocity and relative humidity increase. The third group, represented by carbon dioxide concentration and fungi colonies forming units, presented strong positive association with embryo mortality increase.

\section{INTRODUCTION}

According to Martins et al. (2006), the future of poultry production is linked to flock health. Recent episodes of global epidemics such as Avian Influenza are warnings of the vulnerability of modern poultry production. This scenario indicates the need to provide adequate health and environment to the flock since the hatchery. Proper handling and homogeneous environment in the hatchery are incubation factors that may determine both the development and the growth of broiler chickens.

Until recently, the knowledge on incubation was not as developed as on other areas of the broiler production chain (Calil, 2007). The knowledge built during the last years in poultry nutrition, health, management and environment was not followed by the field of incubation. Incubation factors were only recently recognized as important influences on broiler performance (Decuyere et al., 2001; Tona et al., 2003). Pullet production and performance is affected by the incubation environment, which depends on adequate management and environment homogeneity (Decuypere \& Michels, 1992). Bramwell (2002) states that hatching quality has improved with better environmental control. 
Nääs IA, Gigli ACS, Baracho MS, Almeida Paz ICL, Salgado DD
Embryo development needs are very specific, and the environment must meet these requirements in order to achieve high hatching standards for the different genetic strains (Boleli, 2003; Muraroli \& Mendes, 2003; Boerjan, 2006).

Modern broiler strains with fast growth rate produce more heat during embryonic development especially during the final stages (Mauldin, 2001). Lourens (2006) points out that the heat generated inside incubators today is nearly twice as much as that observed in the 1980s, and that typical machines seldom provide an optimal internal environment, resulting in lower hatchability. The optimal temperature inside the incubator has been the subject of many studies in current literature, showing that variations of $\pm 1^{\circ} \mathrm{C}$ may negatively impact hatching time (French, 1997; Wilson, 1991; Gustin, 2003a). Heat conductivity outside the egg is the most important barrier for heat loss, and it is directly related to air velocity (Gustin, $2003 \mathrm{~b}$ ). However, setters and hatchers often use temperature values as setting points leading to losses that are not easily detected under commercial conditions (Kaltofen, 1969; Wilson, 1991; French, 1997).

Ambient relative humidity is also an important variable during incubation, and should remain within a 40-70\% range (Robertson, 1961; Lundy, 1969; Decuypere et al., 2003). Aerial environment, considering the presence of fungi and carbon dioxide concentration, also may influence hatchability. Li \& Yang (2004) found that fungus exposure during embryonic development may result in irreversible negative effects. During the first four days of life, the embryo requires carbon dioxide due to calcium mobilization, and after that, it needs that gas for its development; however, slight changes in optimal gas ratios may reduce hatchability (Alda, 2003).

This research study aimed at investigating the environmental conditions of hatcheries in order to determine the impact of environmental variables on hatchability.

\section{MATERIAL AND METHODS}

The experiments were carried out in a commercial hatchery located in Amparo, State of São Paulo, Brazil, longitude $46^{\circ} 46^{\prime} 25^{\prime \prime} \mathrm{W}$, latitude $22^{\circ} 43^{\prime} 17^{\prime \prime} \mathrm{S}$, and altitude $683 \mathrm{~m}$ during five batches of chick production. The fertile eggs used in this study were selected from 36-week-old breeder flocks.
Estimating the Impact of Environmental Conditions on Hatching Results Using Multivariable Analysis

\section{Studied parameters}

Environmental conditions such as dry bulb temperature $\left(\mathrm{DBT},{ }^{\circ} \mathrm{C}\right)$, relative humidity $(\mathrm{RH}, \%)$, carbon dioxide concentration $\left(\mathrm{CO}_{2}, \mathrm{ppm}\right)$, air velocity $\left(\mathrm{AV}, \mathrm{m} \mathrm{s}^{-1}\right)$ and number of colony forming units of fungi (CFU) were recorded inside a broiler -multi-stage setter, inside a hatcher after egg transference, and in the vaccination room.

Data on thermal and air conditions inside the setter, the hatcher, and chick room were recorded on the $4^{\text {th }}$, $10^{\text {th }}, 12^{\text {th }}, 16^{\text {th }}$, and $20^{\text {th }}$ day of incubation in five batches.

\section{Experimental procedure}

The monitored areas were divided into quadrants (Figures 1, 2, and 3) in order to measure the parameters with higher precision. The data loggers were placed $1 \mathrm{~m}$ above the floor, in the geometric center of each quadrant.

DBT and RH data were continuously recorded, and $\mathrm{CO}_{2}$ concentration and UFC were recorded daily in the morning.
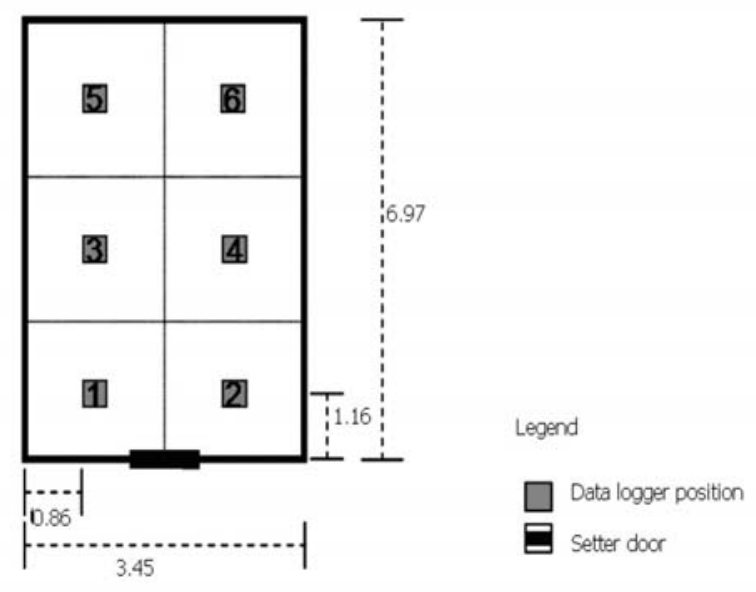

Figure 1 - Scheme of the interior of the setter, and the position of the data loggers.

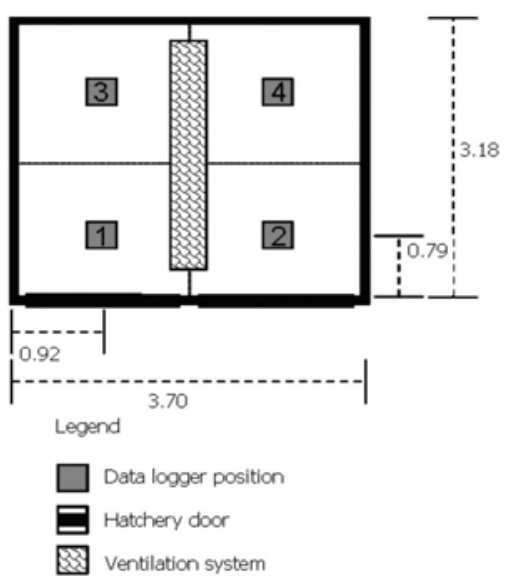

Figure $\mathbf{2}$ - Scheme of the interior of the hatcher, and the position of the data loggers. 
Nääs IA, Gigli ACS, Baracho MS, Almeida Paz ICL, Salgado DD

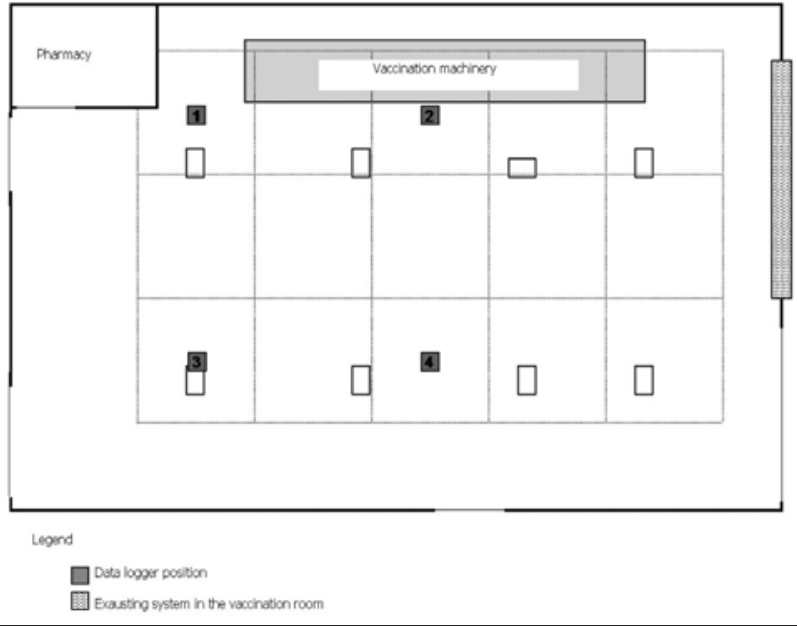

Figure 3 - Scheme of the chick room and the distribution of the data loggers.

After hatching, chicks were transferred to the chick room. Environmental data loggers were randomly placed in the room, with priority given to those places close to the vaccination tables as well as near the chick delivery boxes.

The schedule of environmental monitoring is described in Table 1.

\begin{tabular}{|c|c|c|}
\hline $\begin{array}{c}\text { Incubation day } \\
4^{\text {th }}\end{array}$ & Place of sampling & Parameter \\
\hline $12^{\text {th }}$ & Setter & $\mathrm{DBT} ; \mathrm{RH} ; \mathrm{AV} ; \mathrm{CO}_{2} ; \mathrm{CFU}$ \\
\hline $16^{\text {th }}$ & & \\
\hline $18^{\text {th }}$ & \multicolumn{2}{|c|}{ Eggs transferred to hatcher } \\
\hline $20^{\text {th }}$ & Hatcher & $\mathrm{DBT} ; \mathrm{RH} ; \mathrm{AV} ; \mathrm{CO}_{2} ; \mathrm{CFU}$ \\
\hline $21^{\text {st }}$ & Hatching & \\
\hline Vaccination & Vaccination room & $\mathrm{DBT} ; \mathrm{RH} ; \mathrm{AV} ; \mathrm{CO}_{2} ; \mathrm{CFU}$ \\
\hline
\end{tabular}

Environmental DBT and $\mathrm{RH}$ were recorded in data loggers, whereas thermo-hydro anemometers were used to measure AV. Carbon dioxide concentration was sampled using a portable pump and short-term carbon dioxide reagent tube $\left(5.0 \times 10^{-2} \mathrm{~mol} \mathrm{~m}^{-3}-13.4 \times 10^{-2}\right.$ $\mathrm{mol} \mathrm{m}^{-3}$ ) attached to the pump. CFU was measured inside the broiler multi-stage setter and inside the hatcher after eggs transference. Air sampling methodology was applied by exposing Petri dishes containing Complete Media Culture to the air for $15 \mathrm{~min}$ (Pontecorvo et al., 1953). After exposure, the Petri dishes were incubated at $27^{\circ} \mathrm{C}$ for three days, after which fungi colonies were counted and identified according to fungus genus morphology (Raper \& Fennell, 1965).

Production indexes were provided by the hatchery management after each batch and included hatching
Estimating the Impact of Environmental Conditions on Hatching Results Using Multivariable Analysis

of first and second quality chicks, and mortality. Embryos were controlled using embryo diagnosis method which was carried out according to the incubation phase (1-7, 8-14, 15-18 and 19-21 days of incubation), and recording percentage of embryo mortality, pipped eggs with live or dead chicks, cracked eggs, rotten eggs, contaminated eggs (fungi and bacteria), and chick quality (open cranium, eye and beak malformations, exposed viscera, and leg problems).

\section{Statistical Analysis}

The homogeneity of the data distribution between quadrants inside the setter, the hatcher, and the chick room was tested using the non-parametric test of Kruskal-Wallis with an interval of confidence of $95 \%$. After testing the homogeneity of distribution, a capability tool test was applied to evaluate each environmental parameter in order to compare the recorded values with the recommended ones. Main Component Analysis Technique was used to correlate or associate the parameters by observing the vectors magnitude and angle. Vectors represent different parameters in the data base. Vectors associated in the similar direction (an approximate angle of $0^{\circ}$ between them) are strongly positively correlated, and in the opposite direction (an approximate angle of $180^{\circ}$ between them) indicate strong negative correlation. Vectors showing an angle close to $90^{\circ}$ are not correlated. The longer the vector, the best the technique explains the correlation.

Data were statistically analyzed using the software package Minitab 15 (Minitab, 2006), and multivariate analysis was applied to identify the existence of correlations between environmental and production parameters using the Principal Component Analysis Technique.

\section{RESULTS AND DISCUSSION}

Results are presented and discussed per environmental parameter in the three different environmental conditions present in the multi-stage setter, hatcher, and chick room.

\section{Dry bulb temperature}

ANOVA results showed that DBT data did not present normal distribution. The non-parametric test of Kruskal-Wallis was used to verify the homogeneity of DBT values inside the setter along five batches. DBT upper limit was set at $38.2^{\circ} \mathrm{C}$, while the lower limit 
Nääs IA, Gigli ACS, Baracho MS, Almeida Paz ICL, Salgado DD was $37.2^{\circ} \mathrm{C}$, according to current literature (French, 1997; Wilson, 1991; Gustin, 2003a,b). The analysis of DBT fit to the optimal values shows that at the confidence interval of the DBT recorded values were below the optimal limits in all quadrants $(98.0 \%)$, and the sample mean was $35.4 \pm 0.98^{\circ} \mathrm{C}$, as seen in Figure 4. Even though DBT values between quadrants were similar ( $p$ value>0.05), there was a significant variation within quadrants, and all values were below the optimal.

Departure from optimal temperature inside setter may cause embryo death and increase the time for hatching (Gustin, 2003b). According to French (1997), embryos are sensitive to low temperature in the beginning of the incubation process; however, there may be compensatory growth if DBT reaches 35.0 to $40.5^{\circ} \mathrm{C}$. In the present experiment, $17 \%$ of the recorded DBT were below this limit indicating production loss.

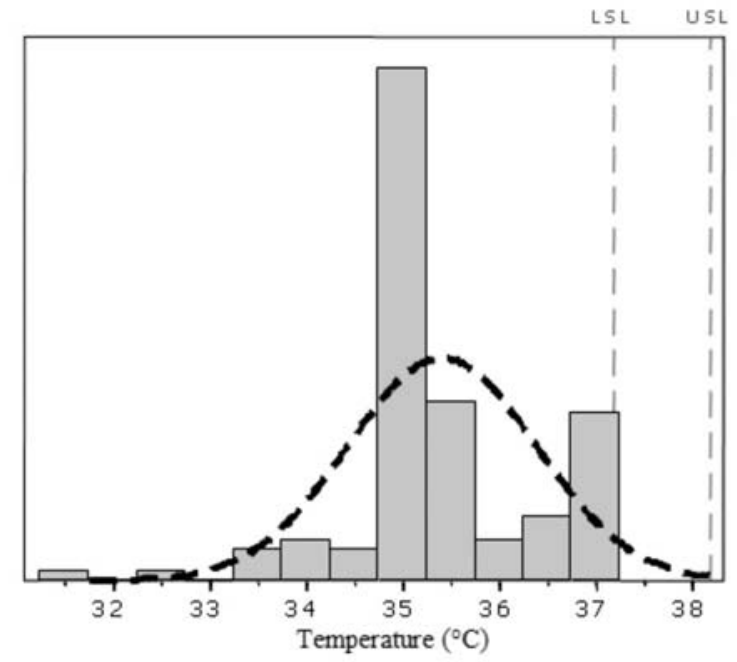

LSL= Lower limit; USL=Upper limit

Figure 4 - Fit analysis of ambient dry bulb temperature inside the multi-stage setter.

Dry bulb temperature inside the hatcher presented a mean value of $35.09 \pm 1.4^{\circ} \mathrm{C}$, and the upper limit was fixed in $37.5^{\circ} \mathrm{C}$, while the lower limit was set at $37^{\circ} \mathrm{C}$, as suggested by Mauldin (2001). Even though data within quadrants were homogenous, DBT values were generally below optimal (90\%), as seen in Figure 5 . Low hatcher temperature is the most probable cause of abnormalities in chicks, in addition, it increases incubation time (Boleli, 2003).

DBT data inside the chick room presented a mean value of $25.30 \pm 0.46^{\circ} \mathrm{C}$, and despite the variation between quadrants, most DBT values were within the
Estimating the Impact of Environmental Conditions on Hatching Results Using Multivariable Analysis

upper limit $\left(28^{\circ} \mathrm{C}\right)$ and the lower limit $\left(22^{\circ} \mathrm{C}\right)$, as shown in Figure 6 . The thermal comfort zone of chicks is in the range of 33 to $36^{\circ} \mathrm{C}$ (Schmidt, 2007). According to that author, the optimal room temperature needs to be between 22 and $28^{\circ} \mathrm{C}$, since the ambient temperature inside the box is usually 6 to $8^{\circ} \mathrm{C}$ above room temperature.

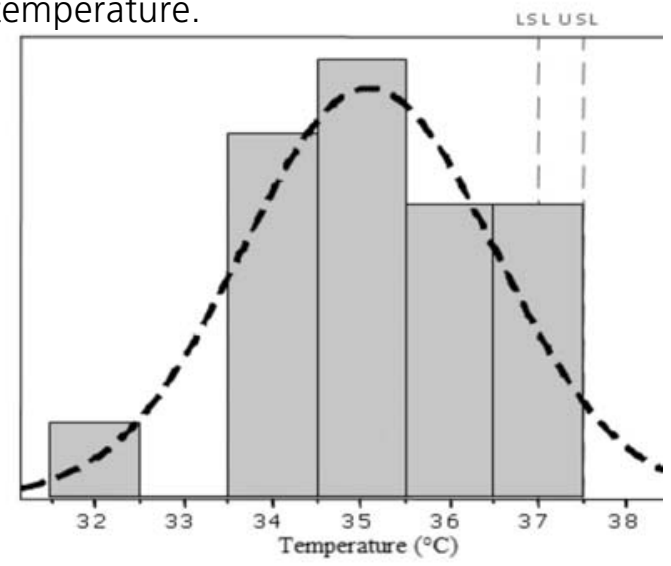

LSL= Lower limit; USL=Upper limit

Figure $\mathbf{5}$ - Fit analysis of ambient dry bulb temperature inside hatcher.

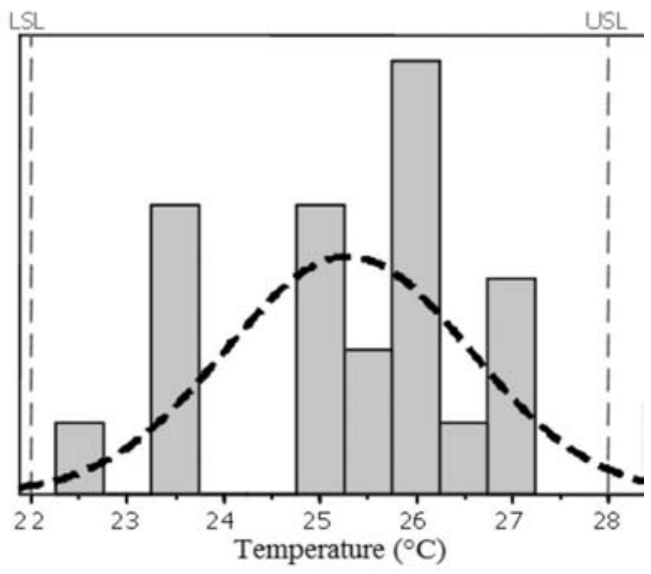

$\mathrm{LSL}=$ Lower limit; USL=Upper limit

Figure 6 - Fit analysis of ambient dry bulb temperature inside the chick room.

\section{Relative humidity}

Relative humidity upper limit in setter was established at $70 \%$ and the lower limit at $40 \%$. The optimal value is $50 \%$, as recommended by Robertson (1961) and Lundy (1969). Figure 7 shows that inside the setter nearly $12 \%$ of the recorded data were below the lower limit. The mean value was $53.70 \pm 1.60 \%$. Although the mean value was near optimal, there was significant variation among the values recorded inside each quadrant as well as among quadrants. 
Figure 8 presents the variation among ambient $\mathrm{RH}$ values recorded inside the hatcher. The mean value was $65.54 \pm 4.41 \%$. Boleli (2003) points out high relative humidity values in the hatcher as a probable cause of the incidence of chicks with exposed viscera, which was also observed in the present trial. On the other hand, low RH may lead to water loss by the embryo and delay hatching time (Decuypere et al., 2003). Significant variation among $\mathrm{RH}$ values was found in all measured quadrants in the present experiment.

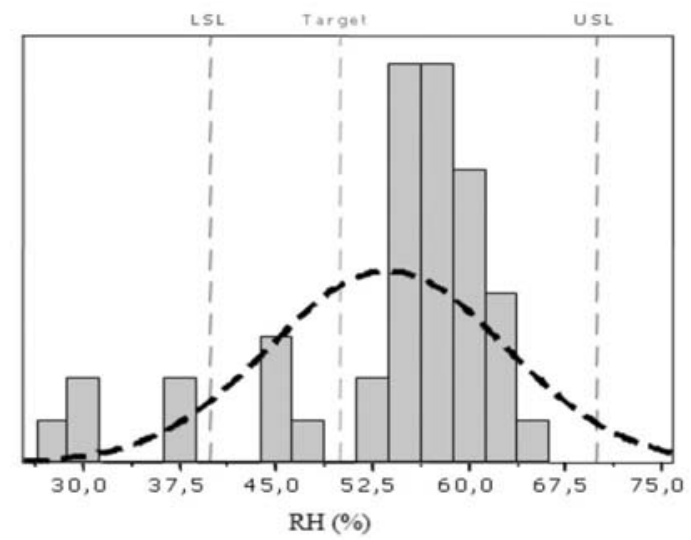

LSL= Lower limit; USL=Upper limit

Figure 7 - Fit analysis of relative humidity inside the multi-stage setter.

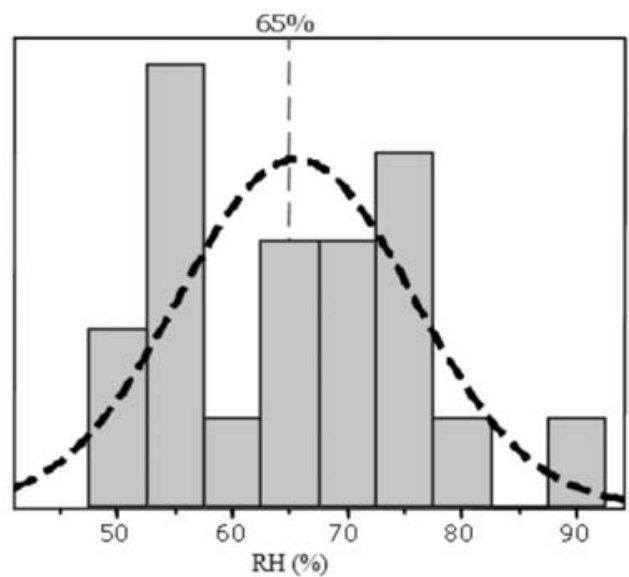

LSL= Lower limit; USL=Upper limit

Figure $\mathbf{8}$ - Fit analysis of relative humidity inside the hatcher.

Inside the chick room, the recorded $\mathrm{RH}$ values were significantly homogenous within quadrants; however, values recorded among quadrants were significantly different. Figure 9 shows that nearly $76 \%$ of the recorded data were above the $60 \%$ recommended by Schmidt (2007).

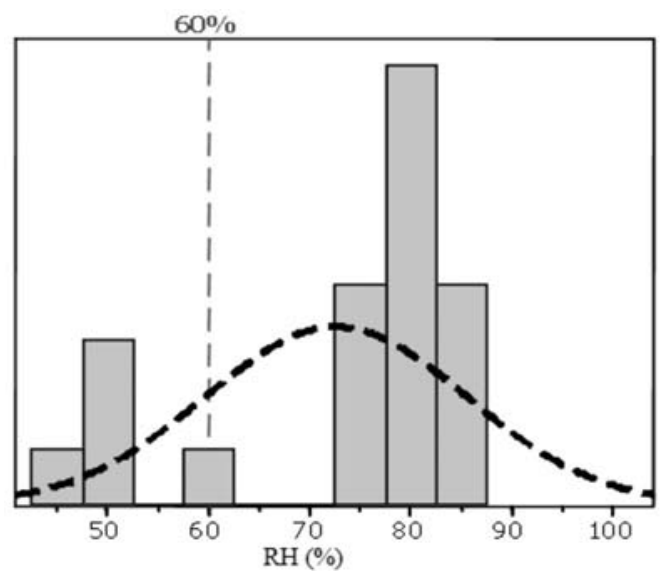

Figure 9 - Fit analysis of relative humidity inside the chick room.

\section{Air velocity}

Air velocity distribution inside the multi-stage setter was homogeneous ( $p$ value>0.05) within quadrants; however, it varied among quadrants, reaching up to 4 $\mathrm{m} \mathrm{s}^{-1}$. High air velocity leads to heat loss by convection and may significantly reduce dry bulb temperature in some places within the setter, causing negative impact in embryo development (Gustin, 2003b). Air velocity was relatively homogeneous among quadrants inside the hatcher, despite the detection of high values near the door. This causes heat loss by convection impacting in the chick quality (French, 1997).

Low air velocity values were found $\left(\sim 0.01 \mathrm{~m} \mathrm{~s}^{-1}\right)$ in some quadrants of the chick room. Air renewal provides better environment for the chicks and minimal ventilation is required.

\section{Carbon dioxide}

No difference was found ( $p$ value $>0.05$ ) in the homogeneity of $\mathrm{CO}_{2}$ distribution inside the setter. $\mathrm{CO}_{2}$ values were low $(0.1 \%)$. Mauldin (2001) states that hatchability is reduced when ambient carbon dioxide rises above $0.5 \%$. In the present experiment, $\mathrm{CO}_{2}$ concentration did influence hatchability. Also in the hatcher, $\mathrm{CO}_{2}$ concentration was low $(>0.2 \%)$, as the recommended lower limit is 0.75\% (Mauldin, 2001). The same results were found in the chick room.

\section{CFU}

Fungi CFU values and identification are shown in Table 2 . The mean results can be considered between good and average (Tessari et al., 2002), although efficient biosecurity and quality control program are recommended to reduce hazardous fungi influence on the environment. However, high Aspergillus fumigatus values (UFC $>5$ ) recorded on the 12th day of incubation 
of flock 2 are considered a health risk to the embryos, according to Back (2007). Deep disinfection process is usually required for controlling fungi in the setter (Lima et al., 2001).

\begin{tabular}{|c|c|c|c|c|c|}
\hline Genus and species & Flock 1 & Flock 2 & Flock 3 & Flock 4 & Flock 5 \\
\hline Acremonium & 2 & 0 & 0 & 0 & 7 \\
\hline Aspergillus flavus & 7 & 3 & 0 & 0 & 4 \\
\hline Aspergillus fumigatus & 2 & 45 & 7 & 0 & 0 \\
\hline Aspergillus glaucus & 2 & 0 & 0 & 0 & 0 \\
\hline Aspergillus niger & 1 & 0 & 0 & 0 & 0 \\
\hline Aspergillus versicolor & 6 & 0 & 4 & 0 & 0 \\
\hline Arthrobotrys & 0 & 0 & 0 & 0 & 2 \\
\hline Bipolaris & 0 & 0 & 0 & 0 & 2 \\
\hline Cladosporium & 22 & 0 & 0 & 5 & 4 \\
\hline Fusarium & 6 & 4 & 0 & 0 & 0 \\
\hline Microsporum & 1 & 0 & 0 & 0 & 0 \\
\hline Neurospora & 0 & 0 & 0 & 0 & 1 \\
\hline Oidium & 0 & 0 & 0 & 0 & 1 \\
\hline Paecilomyces & 0 & 0 & 0 & 0 & 5 \\
\hline Penicillium & 37 & 0 & 0 & 2 & 0 \\
\hline Rhizopus & 6 & 3 & 1 & 0 & 0 \\
\hline Trichoderma & 1 & 0 & 0 & 0 & 0 \\
\hline Trichotecium & 1 & 0 & 0 & 1 & 0 \\
\hline Not identified & 8 & 1 & 1 & 0 & 2 \\
\hline
\end{tabular}

No difference was found in fungi distribution among quadrants in the hatcher ( $p$ value>0.05); however, the recorded values indicate the need of a better disinfection program (Tessari et al., 2002). High fungi presence in the air environment inside the hatcher may compromise chick quality, as well as its further development and performance (Back, 2007). Barnes \& Gross (1997) suggest that contamination by Aspergillus is the most probable cause of high mortality of chicks from the first to the third day after hatching. A correlation between chick contamination by fungi and performance losses during rearing was also observed (Braem, 1988; Cervantes, 1995).

In the chick room, data were homogenous. According to Tessari et al. (2002), the classification can be adopted as average, even though in quadrant 2 CFU values were above 13, indicating a focus of contamination in that specific area. Fungi spores in airborne particles inside vaccination room can indicate contamination in the machines, leading to cross contamination during vaccination, consequently affecting the chicks (Tessari et al., 2002).

\section{Production indexes}

Table 3 shows the production data of the studied flocks. As recommended by Gonzales \& Café (2003), both physical defects and general appearance were observed.

\begin{tabular}{|c|c|c|c|c|c|}
\hline \multirow[t]{2}{*}{ Flock } & \multirow[t]{2}{*}{ Parameter } & \multicolumn{2}{|c|}{ Genetic strain 1} & \multicolumn{2}{|c|}{ Genetic strain 2} \\
\hline & & Number & $\%$ & Number & $\%$ \\
\hline \multirow[t]{6}{*}{1} & Incubated eggs & 30,104 & - & * & * \\
\hline & Average weight $(\mathrm{g})$ & 69.8 & & * & * \\
\hline & Hatched & 27,405 & 91.0 & * & * \\
\hline & Dead & 309 & 1.02 & * & * \\
\hline & First-quality chicks & 27,000 & 86.7 & * & * \\
\hline & Second-quality chicks & 96 & 0.30 & * & * \\
\hline \multirow[t]{6}{*}{2} & Incubated eggs & 20,737 & - & * & * \\
\hline & Average weight (g) & 70.3 & & * & * \\
\hline & Hatched & 17,498 & 84.4 & * & * \\
\hline & Dead & 212 & 1.02 & * & * \\
\hline & First-quality chicks & 17,100 & 82.5 & * & * \\
\hline & Second-quality chicks & 186 & 0.90 & * & * \\
\hline \multirow[t]{6}{*}{3} & Incubated eggs & 7,680 & - & 13,056 & - \\
\hline & Average weight $(\mathrm{g})$ & 69.5 & - & 70.0 & \\
\hline & Hatched & 6,579 & 85.7 & 10,589 & 81.1 \\
\hline & Dead & 131 & 1.71 & 160 & 1.23 \\
\hline & First-quality chicks & 6,400 & 83.3 & 10,400 & 79.6 \\
\hline & Second-quality chicks & 48 & 0.63 & 29 & 0.20 \\
\hline \multirow[t]{6}{*}{4} & Incubated eggs & 6,228 & - & 13,140 & - \\
\hline & Average weight $(\mathrm{g})$ & 70.1 & & 69.3 & \\
\hline & Hatched & 4,694 & 75.4 & 9,239 & 70.31 \\
\hline & Dead & 233 & 3.74 & 171 & 1.30 \\
\hline & First-quality chicks & 4,300 & 69.0 & 8,900 & 67.73 \\
\hline & Second-quality chicks & 161 & 2.59 & 168 & 1.28 \\
\hline \multirow[t]{6}{*}{5} & Incubated eggs & 13,824 & - & 6,912 & - \\
\hline & Average weight $(\mathrm{g})$ & 69.0 & & 69.7 & \\
\hline & Hatched & 11,833 & 85.6 & 5,457 & 78.95 \\
\hline & Dead & 259 & 1.87 & 181 & 2.62 \\
\hline & First-quality chicks & 11,500 & 83.2 & 5,200 & 75.23 \\
\hline & Second-quality chicks & 74 & 0.54 & 76 & 1.10 \\
\hline
\end{tabular}

*Data could not be recovered

The results obtained with the Main Component technique are presented in Figure 10, showing that the environmental parameters can be divided in three distinct groups.

The first group is represented by temperature, which is positively related to good hatchability as well as good chick quality. This classification shows that the parameters "maximum temperature" and "average temperature" have strong direct association with parameters indicating favorable live performance of the chicks. Temperature is the most important and critical environmental factor, and can directly interfere in embryonic development. In the present study, ambient temperatures were considered low as compared to literature recommendations due to the high rate of air convection, consequently affecting embryonic development and causing embryo abnormalities (Boleli, 2003). According to Decuypere et al. (2003), temperature should be maintained within a fixed range in order to assure good results.

The second group of environmental parameters show that poor chick quality is positively related to high air velocity and relative humidity. The fact that 
productivity improves as temperature increases suggests that the optimal environmental temperature to maximize productivity (both in quantity and quality) should be higher than the set points currently used.

The results suggest that increasing ambient temperature may lead to better hatchability provided that temperature variability is controlled. This second group of parameters presented, in general, negative association with hatchability. The parameters relative humidity and air velocity presented positive association with the increase in the number of low-quality chicks.

The third group, represented by carbon dioxide concentration and fungi colony forming units, presented strong positive association with increase in mortality and in the number of culled chicks.

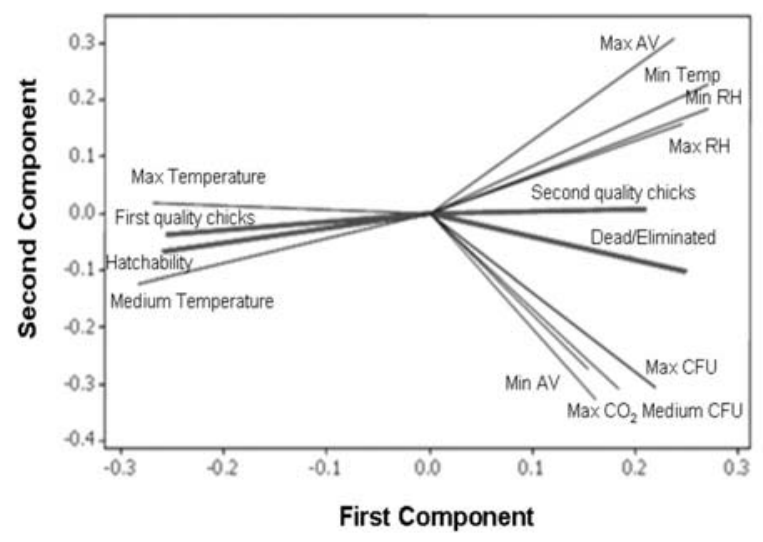

Figure 10 - Main Component graph correlating environmental parameters during incubation to production data.

High relative humidity, high carbon dioxide concentration, and high fungi concentration are stressed as parameters associated to low hatchability, leading to increased mortality. Poor incubation results are observed when the combination of high or low environmental temperature and relative humidity is inadequate inside the hatcher for a determined period (De Smit et al., 2006), and when the lack of ventilation affects oxygen renewal (Alda, 2003; MSU, 2004).

Embryonic mortality may occur due to fungi (Aspergillus and Penicillium spp.) contamination during the incubation process. As the hatchery is an ideal environment for fungi development (high temperature, high relative humidity, high level of organic matter, and presence of cracked eggs), adequate control of these fungi species is a requirement of biosecurity programs.

Current literature indicates that embryos under high humidity stress tend to hatch early, before reaching its full development (Decuypere et al., 2003). High carbon dioxide concentrations may also reduce hatching rate
(Mauldin, 2001). The present experiment showed that $\mathrm{CO}_{2}$ concentration was positively associated with embryo mortality. The incidence of abnormalities was linked to low ambient temperature during incubation, and highly correlated to fungi contamination that, despite not being considered high according to Tessari et al. (2002), was enough to negatively impact chick production volume and quality.

\section{CONCLUSIONS}

The environmental data collected inside the multistage setter and in the chick room did not present homogeneity. The vectors of maximum dry bulb temperature were highly correlated both to hatchability and to first-quality chick numbers. Mortality was slightly correlated to fungi CFU, minimum air velocity, and maximum carbon dioxide concentration.

\section{REFERENCES}

Alda TRBL. Embrio-diagnóstico. In: Macari M, Gonzales E, editores. Manejo da incubação. 2. ed. Campinas: FACTA; 2003. p.499-514.

Back A. Incubatório: monitoria microbiológica pela exposição de placas [cited 2007 mar]. Available from: http://www.aveworld.com. br/index.php? documento $=1432$.

Barnes HJ, Gross WB. Colibacilosis. In: Calnek BW. Disease of poultry. 10th ed. Ames: lowa State University Press; 1997. p.131-141.

Boerjan ML. Incubação em estágio único para melhorar a uniformidade. Anais da Conferência APINCO de Ciência e Tecnologia Avícolas; 2006; Santos. São Paulo. Brasil. p.325-333.

Braem G. Limiting Aspergillus in the hatchery. International Hatchery Practice 1988; 2(8):11-13.

Boleli IC. Estresse, mortalidade e malformações embrionárias In: Macari M, Gonzales E, editores. Manejo da incubação. 2.ed. Campinas: FACTA; 2003. p.472-498.

Bramwell RK. Egg shell mottling and hatchability [cited 2002 jul 28]. Available from: http://www.thepoultrysite.com/FeaturedArticle/ FATopic.asp?AREA=Incubation\&Display $=28$

Calil TAC. Princípios básicos de incubação. Anais da $25^{\text {th }}$ Conferência APINCO de Ciência e Tecnologia Avícolas; 2007 mai 29-31; Santos. São Paulo. Brasil. Campinas: FACTA; 2007.

Cervantes $\mathrm{H}$. Evaluación y manejo de los problemas respiratórios em pollos de engorde. Avicultura Profesional 1995; 13(2):74-84.

Decuypere $\mathrm{E}$, Michels $\mathrm{H}$. Incubation temperature as a management tool: a review. World's Poultry Science Journal 1992; (48):28-38.

Decuypere E, Tona K, Bruggeman V, Bramelis B. The day-old chick: 
A crucial hinge between breeders and broilers World's Poultry Science Journal 2001; (57):127-138.

Decuypere E, Malheiros RD, Moraes VMB, Bruggeman V. Fisiologia do embrião. In: Macari M, Gonzales E, editores. Manejo da incubação. 2. ed. Campinas: FACTA; 2003. p.65-94.

De Smit L, Bruggeman V, Tona JK, Debonne M, Onagbesan O, Arckens L, De Baerdemaeker J, Decuypere E. Embryonic developmental plasticity of the chicken: increased $\mathrm{CO}_{2}$ during early stages of incubation changes the developmental trajectories during prenatal and postnatal growth. Comparative Biochemistry and Physiology: Part A 2006; 145:166-175.

French NA. Modeling incubation temperature: the effects of incubator design, embryonic development, and egg size. Poultry Science 1997; (76):124-133.

Gonzales E, Café MB. Produção de pintinhos com qualidade total. In: Macari M, Gonzales E, editores. Manejo da incubação. 2. ed. Campinas: FACTA; 2003. p. 515-526.

Gustin PC. Biossegurança no incubatório. In: Macari M, Gonzales E, editores. Manejo da incubação. 2. ed. Campinas: FACTA; 2003a. p. 297-352.

Gustin PC. Gerenciamento administrativo e controle de qualidade do incubatório. In: Macari M, Gonzales E, editores. Manejo da incubação. 2. ed. Campinas: FACTA; 2003b. p.472-498.

Kaltofen KS. The effect of air movements on hatchability and weight loss of chicken eggs during artificial incubation. In: Carter TC, Freeman BM. The fertility and hatchability of the hen's egg. Edinburg, UK: Oliver \& Boyd; 1969.

Li DW, Yang C. Notes on indoor fungi I: new records of and noteworthy fungi growing in indoor environments. Mycotaxon 2004; (89):373-488

Lima JSJ, Pinto DM, Carrasco LO, Salguero FJB, Meireles MCA. Incidência de fungos na produção de pintos de corte de um dia de idade. Revista Brasileira de Agrociência 2001; 7(1):73-77.

Lourens A, Molenaar R, Vander BH, Heertkamp MJW, Meijerhof R, Kemp B. Effect of egg size on heat production and transition of energy from egg to hatching. Poultry Science 2006; 85:770-776.

Lundy $\mathrm{H}$. A review of the effects of temperature, humidity, turning and gaseous environment in the incubator on hatchability of hen's eggs. In: Carter TC, Freeman BM. The fertility and hatchability of the hen's egg. Edinburg, UK: Oliver \& Boyd; 1969.

Mauldin JM. Factors affecting hatchability. In: Bell DD, Weaver WD. Commercial chicken meat and egg production. 5th ed. Norwell: Kluwer Academic Publishers; 2001. p.727-773.

Martins FM, Talamini DJD, Novaes M. Avicultura: Situação e perspectivas brasileira e mundial. Ave World 2006; 4(20):21-30.

Minitab. Minitab 15.1.0.0. State College: Minitab; 2006.

MSU - MISSISSIPI STATE UNIVERSITY EXTENTION SERVICE. Important incubation factors. 2004 [cited 2007 mar]. Available from: http://www.thepoultrysite.com/articles/151/importantincubation-factors.

Muraroli A, Mendes AA. Manejo da incubação, transferência e nascimento do pinto. $\mathrm{n}$ : Macari $\mathrm{M}$, Gonzales $\mathrm{E}$, editores. Manejo da incubação. 2. ed. Campinas: FACTA; 2003. p.180-198.

Pontecorvo G, Roper JA, Hemmons DW, Mac Donald KD, Bufton AW. The genetics of Aspergillus nidulans. Advances in Genetics 1953; 5:141-238.

Raper KB, Fennell DI. The genes Aspergillus. Baltimore, USA: Williams \& Wilkins Co; 1965.

Robertson IS. Studies in the effect of humidity on the hatchability of hen's eggs. I. The determination of optimum humidity for incubation. Journal of Agricultural Science 1961; 57:185-194.

Schmidt GS. Incubação: condições prevalecentes entre o nascimento e o alojamento dos pintos [cited 2007 oct]. Available from: http:// www.aveworld.com.br/index.php?documento $=121$.

Tessari ENC, Cardoso ALSP, Castro AGM, Kanashiro AMI, Zanatta GF. Avaliação das condições sanitárias de incubatório de pintos de corte. Arquivo Instituto Biológico 2002; 69(3):1-4.

Tona K, Bamelis F, DE Ketelaere B, Bruggeman V, Moraes VMB, Buyse J, Onagbesan O, Decuypere E. Effects of Egg Storage Time on Spread of Hatch, Chick Quality, and Chick Juvenile Growth. Poultry Science 2003; 82:736-741.

Wilson HR. Physiological requirements of the developing embryo: Temperature and turning. In: Tullet SG. Avian licubation. London: Ed. Butterworth-Heinemann; 1991. p. 145-156. 